Available online at http://iddtonline.info

RESEARCHARTICLE

\title{
SYNTHESIS AND CHARACTERIZATION OF SOME METAL COMPLEXES WITH IEA AS LIGAND DERIVED FROM 2-ACETLYLINDAN-1,3-DIONE
}

\author{
*Devesh Kumar', Vipin Kumar Singh ${ }^{2}$ \\ ${ }^{1}$ Research Scholars, Agra College, Dr B.R. Ambedkar University, Agra, India \\ ${ }^{2}$ Research Scholars, Agra College, Dr B.R. Ambedkar University, Agra, India \\ *Corresponding Author's Email: devesh2015@gmail.com
}

\begin{abstract}
:
The present investigation are based on the synthesis and characterization of metal complexes with Schiff's bases (anils) Indeno-ethylidene aniline $\left(\mathrm{C}_{17} \mathrm{H}_{13} \mathrm{O}_{2} \mathrm{~N}\right)$, (IEA), $\left(\mathrm{L}_{1} \mathrm{H}\right)$ derived from 2-substituted acetyl 1, 3 - dione by condensing it with primary aryl amine (aniline) in absolute alcohol. The Co (II), Ni(II), $\mathrm{Cu}$ (II), $\mathrm{Zn}$ (II), $\mathrm{Cd}$ (II), Fe (III), V (III) and Cr (III) complexes of the Schiff's bases have been prepared in the reactions and investigated their structures by physicodemical methods. The formulation and structure of the ligands have been screened by their chemical analysis, IR, PMR and mass-spectral studies. The structure of the anils has been characterized by their IR spectra which showed strong absorption at 1705,1650 and $1570 \mathrm{~cm}^{-1}$ along with other bands. The structure of ligand has been confirmed by their mass-spectral studies.
\end{abstract}

Keywords: Metal Complexes, Schiff's bases, 2-Acetlylindan-1,3-Dione

\section{INTRODUCTION}

Schiff's bases or anills have been found to be immense importance and versatile complexing agents. large number of transition metal complexes have been synthesized and charatarised with schiff's bases which have been proved of wide utility, semicarbazone and thiosemicarbazone have joined special attentation due to their activity against protozoa, influenza, small pox, malaria, tuber-culosis ${ }^{1-2}$, and antitumor activity of their meatal complexes. ${ }^{3-4}$ Metal complexes of thiosemicarbazone have emerged as new class of chemotherapeutic agent which exhibit inhibitory activity against most cancers through inhibition of a crucial enzyme, obligatory for DNA biosynthesis and cell division. Due to wide range of medicinal use of metal complexes of semicarbazone/thiosemicarbazone. $\mathrm{Co}(\mathrm{II}), \mathrm{Ni}(\mathrm{II}), \mathrm{Cu}(\mathrm{II})$ etc. metal complexes with these ligands have been prepared and reported. ${ }^{5-8}$

Because of their versatile biological activity and prospective use as drugs. ${ }^{9}$ Owing to the interest they generate through a variety of biological prosperties ranging from anticancer, ${ }^{10}$ antitumor, ${ }^{11}$ antifungal, ${ }^{12}$ antibacterial ${ }^{13}$ antimalarial, ${ }^{14}$ antitilarial, ${ }^{15}$ antiviral, ${ }^{16}$ anti $-\mathrm{HIV},{ }^{17}$ activities, thiosemicabazones and their metal complexes have been extensively studied.

The ability of thiosemicarbazone molecule to chelate with traces of metals in the biological system is believed to be a reason for their activity. The lipophilicity of thio semi carbazone controls the rate of entry of trace metals into the cell. This modified by cordination and some side effects may be decreased ${ }^{87-88}$. It has been proved that C 2011, JDDT. All Rights Reserved thiosemcarbazone block DNA synthesis in mammalian cells big by inhibiting the enzymes, ribonucleoside diphosphate reductase, presumably either via chelation with an iron ion required by the enzymes or because a performed metal chellate of the inhibitor interacts with the target enzyme ${ }^{18}$. The reports also point out the capacity of thiosemicarbazon to saver the DNA stands ${ }^{19}$.

The antitumor activities of $\mathrm{Mn}$ (II), $\mathrm{Ni}$ (II), and $\mathrm{Cu}$ (II) chelates of anthracene $-9-$ carboxyldehyde thiosemicarbazone 20 and the cytotoxic activity of phenylglyoxal bis (thiosemicarbazone) against Ehrlichascitess carcinoma cells have been reported.

Platinum complexes of 2-acetylpyriden thiosemicarbazone have been synthesized in which intermolecular hydrogen bonds, $\pi-\pi$ and weak pt $-\mathrm{pt}$ and $\mathrm{pt}-\pi$ contacts lead to aggregation and to a two- dimensional supra molecular assembly. The complexes were found to have a completely lethal effect on Gram +ve bacteria.

Thiosemicarbazones are thio urea derivatives obtained by condensation of thiosemicarbazide or N(4)-substituted thiosemicarbazide with a suitable aldehyde or ketone. The thiosemi- carbazones are represented by the general formula and when N(4) is substituted they can represented by the general formula. 

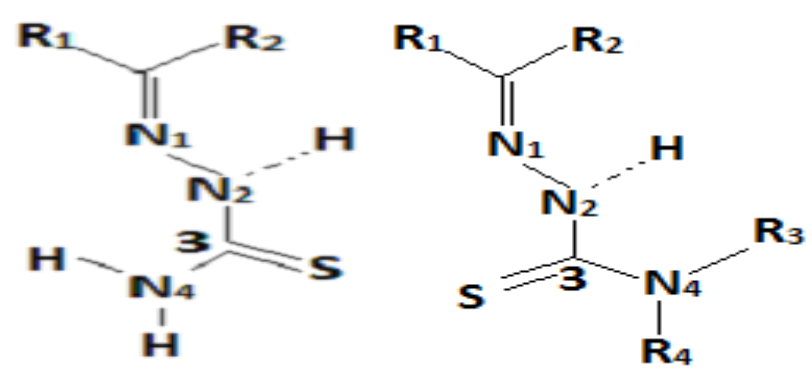

$11 \underline{\mathrm{H}}-$ indeno[1,2- $\mathrm{b}]$ quinoline(3) and $6 \underline{\mathrm{H}}-$ indeno[2,1-b] quinoline (4) have been synthesized and screened for their carcenogenic and antitumor activities. ${ }^{21,22}$

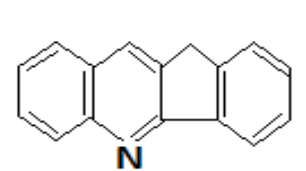

(3)

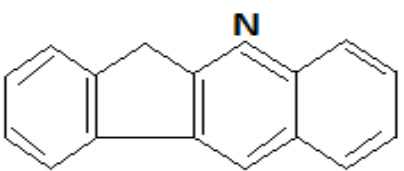

(4)
Houliham and his coworkers ${ }^{23}$ synthesizes 3-substituted2,4-dihydroindeno(1,2- $\underline{\text { C }}$ _pyrazoles and screened them for their antihypertensieve, contraceptive and abortifacient activity. At a level of $1-100 \mathrm{mg} /$ day, pyrazoles $^{24}$ actid as antifertility agent in rats and $2-200 \mathrm{mg} / \mathrm{Kg}$ behaved as antihypertensive agents.

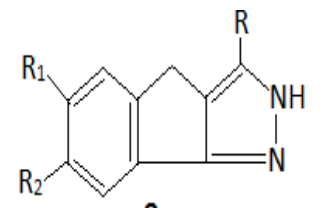

$\mathrm{R}=2 ;, 3 ;$, pyridyl, 2- furyl, 2- thienyl, 9.

$\mathrm{R}_{1}=\mathrm{H}, \mathrm{Cl}, \mathrm{CH}_{3}$ and $\mathrm{OCH}_{3}$

$\mathrm{R}_{2}=\mathrm{H}$ and $\mathrm{OCH}_{3}$

From the detailed survey of the literature on condensed heterocyclic ring systems, it is evedent that indenoquinolenes and indenopyrazoles show various pharmacological and biological properties. Some 10substituted indenoquinolines are potent analgesics and antiinflammatory agents. Among pyrazoles fused to carbocyclic and heterocyclic ring systems, indenopyrazoles occur a uniques position because of their wide spectrum of physiological properties. With this fact a series of substituted indenopyrazoles has been reported.

Indenoquinolines and indenopyrazoles consist of indane-1, 3-dione moiety which may be responsible for their biological activity. This suggests that indanedione derivatives may possitively exhibit this property also. The Schiff's bases have been reported to be good complexing agents.

This seems to be worthwhile to synthesize 2-substituted 1,3-indanedione Ketones and their Schiff's bases (anils) by condensation them with aniline and various isomeric toleredines which could be used as complexing agents to prepare and characterize their metal derivatives. With this fact in thoughts the present research work has been carried out.

The present investigation aims at evolving indeno-anils as ligands by utilizing easily available $2-$ acyl indane $1,3-$ dione and aromatic primary amines etc. as starting materials, and formation of their metal derivatives.

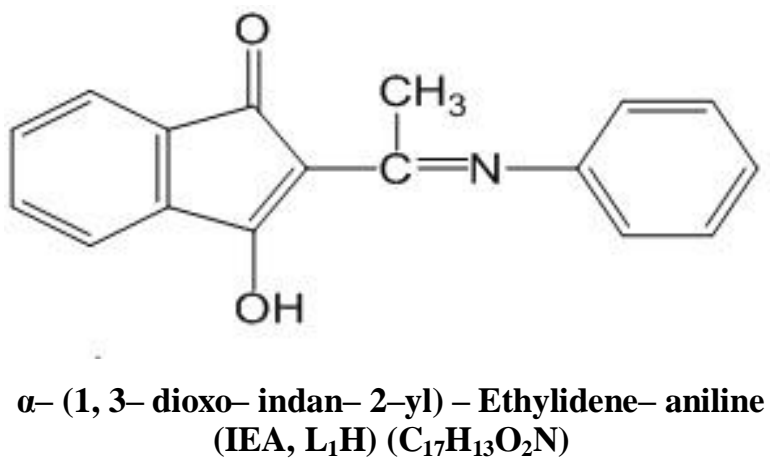

In the present work, the reactions of following anhydrous metal chlorides and the selected indeno-ligands have been studied, the metal derivatives of the ligands been isolated and characterized. i.e. Cobalt (II) chloride, Nickel (II) chloride, Copper (II) chloride, Zinc (II) chloride, Cadmium (II) chloride, Iron (III) chloride, Vanadium (III) chloride, Chromium (III) chloride

\section{MATERIAL AND METHODS}

\section{Material:}

All the chemicals used in this investigation were of good quality and analytical grade and were purchased from standard chemical agencies. Methanol and ethanol were first dried by refluxing over quicklime for four to six hours and then distilled over sodium wire. ${ }^{25,26}$ Acetaldehyde, Benzaldehyde and Acetone were dried over aluminium isoproxide and then distilled fractionally before use. ${ }^{27}$ Aniline and $\mathrm{p}$ - toluidine were dried and distilled before use. Benzene and Thiosemicarbazine were purified and dried before use. Anhydrous metal salts (mostly chlorides) of $\mathrm{Co}(\mathrm{II}), \mathrm{Ni}(\mathrm{II}), \mathrm{Cu}(\mathrm{II}) \mathrm{Zn}(\mathrm{II}), \mathrm{V}(\mathrm{III}), \mathrm{Cr}$ (III) and $\mathrm{Fe}(\mathrm{III})($ all Fluka, A.G. and B.D.H.) were used as such after confirming their purity by chemical analysis.

\section{Analytical methods:}

The composition of ligands and their metal derivatives was determined by elemental analysis such as quantitative analysis of carbon, hydrogen, nitrogen, halogen and metal ions by known standard methods. These studies were carried out in case of few selected ligands and their metal derivatives $^{28}$.

Metal ions were estimated by known standard methods. The complexes were dissolved by decomposing first with concentrated nitric acid and then in hydrochloric acid. The solution was then heated to dryness or neutralized by suitable ways depending upon the method of analysis Iron $^{29}$, Cobalt ${ }^{30}$, Nickel $^{31}$, Copper ${ }^{32}$, Zinc etc. were estimated by known standard methods. 


\section{Physical Measurements:}

\section{Molar Conductance:}

The variation is molar conductance of the metal complexes could be confirmed by molar conductance measurements of the complexes.

The reciprocal of the resistance is termed the conductance measured is reciprocal ohms or

$\Omega^{-1}$. The resistance of a sample of homogeneous solution, length(1), and cross section area (a), is given by:-

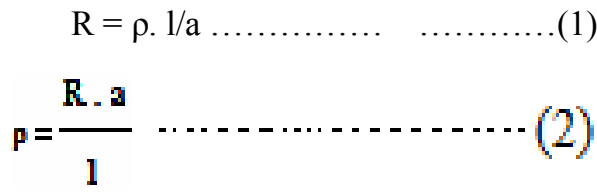

$\mathrm{P}$ is a characterstic property of the material termed the resistivity. It is given by

When "l" and "a" are measured in meters and square meter than " $p$ " is measured in $\Omega$ meters. The reciprocal of resistivity is the conductivity $(\mathrm{K})$. The conductivity of 1 mole of the material is called molar conductance. a/ 1 is characterstic of conductivity cell, called cell constant.

The molar conductance of some selected metal derivatives has been determined by using sensitive conductivity bridge. First, the cell constant is determined. The cell $(x=a / 1)$ must be evaluated by caliberation with a solution of accurately known conductivity e.g. a standard Potassium choloride solution.

\section{Megnatic suspectibility measurements.}

The magnetic susceptibility of the synthesized metal complexes was determined by using "Gouy's" balance. The weights were measured by means of electrical balance. By changing the magnetic field change in weight of the compounds were recorded to determine their magnetic susceptibility values. The formula used is given as

$$
\psi_{\mathrm{m}}=\frac{2 \mathrm{mgL}}{\mathrm{m}^{\prime} \mathrm{H}^{2}} \text { C.G.S. Units. }
$$

formula:-

Where:-

$\mathrm{m}=$ Change in mass of sample in magnetic field(H),

$\mathrm{g}=$ acceleration due to gravity at that place.

$\mathrm{L}=$ Length of compound in the tube.

$\mathrm{m}^{1}=$ mass of compound field in the tube.

The molecule suscotibility is given by equation:

$$
\psi_{\mathrm{M}}=\psi_{\mathrm{m}} \mathrm{x} \text { molecular weight of the compound }
$$

or

$$
\psi_{\mathrm{M}}=\psi_{\mathrm{m}} \times \mathrm{M}
$$

The magnetic susceptibility after diamagnetic correction is given by relation

$$
\mu_{\text {eff }}=2.84 \sqrt{\psi_{\text {sd }} \mathrm{T}} \quad \text { B.M. }
$$

Where, $\mathrm{T}$ is absolute temperature copper sulphate was used as calibrant in all these determinations.

\section{Infra-Red measurement:}

Infra-red spectra of the ligands and their metal derivatives were recorded on Perkin - Elemer, 842-infrared spectrometer using KBr Pallets in the region of $400-4000$ $\mathrm{cm}^{-1}$.

\section{N.M.R. Studies:}

The PMR spectra of ligands and their metal complexes have been recorded by sending samples to research laboratory at K.U Kurushetra(Haryana) and CDRI lucknow. The NMR - studies helped in determining the structure and stereochemistry of the ligands and their metal derivatives.

\section{Mass - Spectral studies:}

The mass- spectrum of ligand and some metal derivatives were recorded on MS-12, mass- spectrometer operating at $70 \mathrm{ev}$. The data given in parentheses represent relative intensities of peaks corresponding to the base peak taken as 100.

\section{Synthesis of ligands:}

In present investigation $\alpha-(1,3-$ dioxo- indan- 2-yl) ethylidne aniline, $\mathrm{L}_{1}$ (IEA) ligand has been used to form its metal derivatives.

The general approach towards synthesis of these indenoligands consists of an initial condensation of 2- substituted indane 1, 3- dione, wih an aromatic primary amines, semicarbazides, thiosemicarbazides etc. The synthesis of starting compound, indane- 1, 3- dione and the ligands containing indane- 1, 3- dione moiety have been synthesized experimentally in research laboratory. The ligands have been characterized by various physicochemical methods.

1. Synthesis of $2-$ Acetyl indane - 1, 3-dione ${ }^{25}$ :It was prepared by claisen - condensation of diethylphthalate and acetone in presence of sodium methoxide. The reaction proceeded through the following steps: 


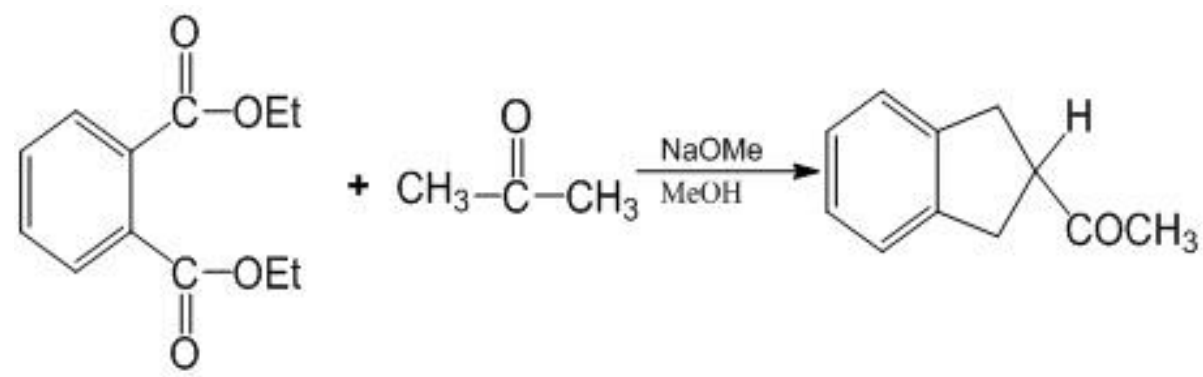

The product was characterized by $1 \mathrm{R}$ and PMR spetral studies observed data are given below:

$$
\underline{\text { IR (Nujaol) } \mathrm{cm}^{-}{ }^{1}}
$$

$1710(\mathrm{~S},>\mathrm{C}=\mathrm{O})$, stretch in a five membered ring $)$

$1670-1620$ (S, Chelated $>\mathrm{C}=\mathrm{O}$ stretch)

$1595(\mathrm{~s}), 1570(\mathrm{~s}), 1450(\mathrm{~s}), 1350(\mathrm{~m}), 1320(\mathrm{~s}), 1230(\mathrm{w}), 980(\mathrm{~m}), 860(\mathrm{~s}), 800(\mathrm{~m})$ and $730(\mathrm{~s})$.

\section{$\underline{\operatorname{PMR}\left(\mathrm{COCl}_{3}\right), \delta}$}

$2.50\left(\underline{\mathrm{S}}, 3 \mathrm{H},-\mathrm{COCH}_{3}\right), 7.40-7.80\left(\underline{\mathrm{m}}, 4 \mathrm{H}, \mathrm{C}_{4}-\mathrm{H}, \mathrm{C}_{5}-\mathrm{H}, \mathrm{C}_{6}-\mathrm{H} \& \mathrm{C}_{7}-\mathrm{H}\right)$ and $12.40\left(\mathrm{C}_{8}-\mathrm{OH}\right)$ enolic.

\section{Synthesis of $\alpha-(1,3-$ dioxoindane $-2-y l)$ ethylidene aniline $(\text { IEA })^{25,29,30}$}

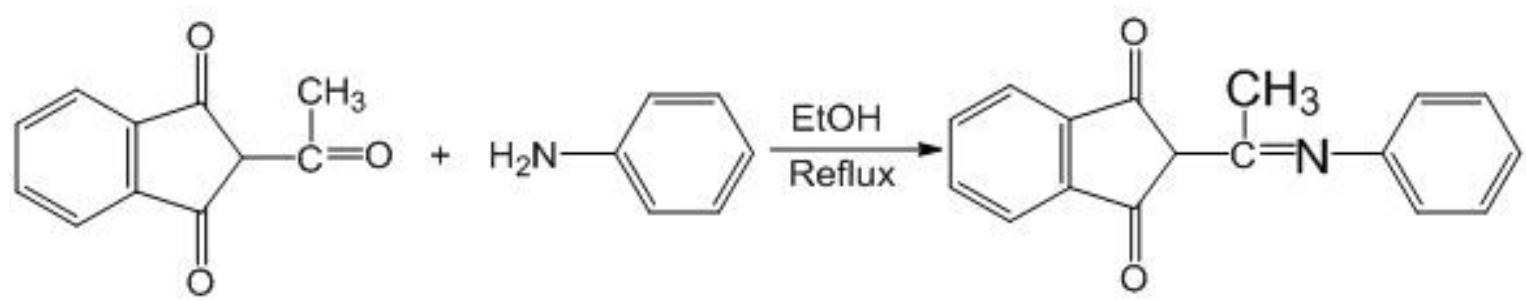

(IEA)

When 2- acetylindane-1,3-dione was refluxed in absolute ethanol with freshly distilled aniline, $\alpha$-(1,3-dioxo indan-2yl) ethylidene aniline was obtained as yellowish green needles. The product was characterized by IR and PMR studies.

$$
\underline{\text { IR (Nujaol) } \mathrm{cm}^{-1}}
$$

$1705(\mathrm{~S},>\mathrm{C}=\mathrm{O})$, stretch in a five membered ring), $1635(\mathrm{~S}, \mathrm{C}=\mathrm{N}-\mathrm{stretch}), 1620(\mathrm{~s}), 1500(\mathrm{~s}), 1440(\mathrm{~m}), 1370(\mathrm{~s}), 1260(\mathrm{~s})$, 1040(m), 960(s), 750(s).

\section{$\underline{\operatorname{PMR}\left(\mathrm{COCl}_{3}\right), \delta}$}

$12.75\left(\underline{\mathrm{S}}, 3 \mathrm{H},-\mathrm{N}=\mathrm{C}-\mathrm{CH}_{3}\right), 7.20-7.60\left(\underline{\mathrm{m}}, 5 \mathrm{H}, \mathrm{C}_{2}-\mathrm{H}\right.$ to $\left.\mathrm{C}_{3}-\mathrm{H}, \mathrm{C}_{4}-\mathrm{H}, \mathrm{C}_{5}-\mathrm{H} \& \mathrm{C}_{6}-\mathrm{H}\right), 7.50-7.90\left(\underline{\mathrm{m}}, 4 \mathrm{H}, \mathrm{C}_{4}-\mathrm{H}, \mathrm{C}_{5}-\mathrm{H}, \mathrm{C}_{6}-\mathrm{H}\right.$ $\left.\& \mathrm{C}_{7}-\mathrm{H}\right), 12.40\left(\underline{\mathrm{Br}}, 1 \mathrm{H}, \mathrm{C}_{3}-\mathrm{OH}\right.$, enolic).

\section{Preparation of metal derivatives:}

The present investigation is based upon the reactions between metal ions and ligand. The metal complexes of metal ions $\mathrm{Co}(\mathrm{II}), \mathrm{Ni}(\mathrm{II}), \mathrm{Cu}(\mathrm{II}), \mathrm{Zn}(\mathrm{II}), \mathrm{Cd}(\mathrm{II}), \mathrm{V}(\mathrm{II}), \mathrm{Cr}(\mathrm{II})$, and $\mathrm{Fe}(\mathrm{III})$ with ligand, indeno-ethylidene aniline(IEA) has been prepared in different molar ratios of metal to ligand.

The general reactions may be represented as follows:

\section{Reactions of ligands with bivalent metal ions; $\mathrm{M}(\mathrm{II})$ in $\mathrm{MeOH}$ solvent: -}

(i) 1:1 molar ratio Reactions: -

$\mathrm{MX}_{2}+\mathrm{L}_{1} \mathrm{H} \longrightarrow$

(ii) $\underline{1: 2 \text { molar ratio Reactions:- }}$

$\mathrm{MX}_{2}+2 \underline{\mathrm{L}} \mathrm{H}$

(x)

$$
\mathrm{ML}_{1} \mathrm{X} \cdot \mathrm{xMeOH}+\mathrm{HX}
$$

$$
\mathrm{M}\left(\mathrm{L}_{1}\right)_{2} \cdot \mathrm{yMeOH}+2 \mathrm{HX}
$$

[x= Cl, M= Co(II), Ni(II), Cu(II), Zn(II), Cd(II)], [x= 3, and y= 2, for Co(II), Ni(II)complexes]. 


\section{Reactions of ligands with trivalent metal ions in $\mathrm{MeOH}$ solvent: -}

(i) 1:1 molar ratio reactions: -

$\mathrm{MX}_{3}+\mathrm{L}_{1} \mathrm{H}$

(ii) 1:2 molar ratio reactions: -

$\mathrm{MX}_{3}+2 \underline{\mathrm{L}} \mathrm{H} \longrightarrow$

(iii) 1:3 molar ratio Reactions: -

$\mathrm{MX}_{3}+3 \mathrm{~L}_{4} \mathrm{H}$
$[\mathrm{x}=\mathrm{Cl}, \mathrm{M}=\mathrm{V}(\mathrm{III}), \mathrm{Cr}(\mathrm{III})$ and $\mathrm{Fe}(\mathrm{III})],[\mathrm{x}=2$, and $\mathrm{y}=1]$.

$$
\mathrm{ML}_{1} \mathrm{X}_{2} \cdot \mathrm{xMeOH}+\mathrm{HX}
$$

$\mathrm{M}\left(\mathrm{L}_{1}\right)_{2} \mathrm{X} . \mathrm{yMeOH}+2 \mathrm{HX}$

\section{RESULTS AND DISCUSSIONS}

The newer heterocyclic compounds have been derived, recently from Indan-1, 3- dione which have been used to synthesize various schiff's base indeno- acetylidene aniline (IEA). These function as complexing agents for metal ions. So far in the survey of literature these compounds have not been used to forms complexes with metal ions with this fact in consideration the present research work has been carried out. This work includes the synthesis of ligand having indane moiety and their metal derivatives and their characterization by spectral studies and elemental analysis.
In the present work, the reactions of following anhydrous metal chlorides and indeno- acetylidene aniline -ligands have been studied, the metal derivatives of the ligands been isolated and characterized. i.e. Cobalt (II) chloride, Nickel (II) chloride, Copper (II) chloride, Zinc (II) chloride, Cadmium (II) chloride, Iron (III) chloride, Vanadium (III) chloride, Chromium (III) chloride

\section{Structere Analysis of The Anil (IEA)}

The structure of this anil has been corroborated by its IR, PMR and mass spectral data given in table-1.

TABLE 1: IR and PMR spectral data of the ligand Indeno- Ethylidene- Aniline (IEA)

\begin{tabular}{|c|c|}
\hline Spectral data & Assignments \\
\hline \multicolumn{2}{|l|}{ (A) IR (Nujol) $\mathrm{cm}^{-1}$} \\
\hline $3610(\mathrm{~s})$ & $v(\mathrm{O}-\mathrm{H})$, stretch, (phenolic) \\
\hline 3060 & $v(\mathrm{C}-\mathrm{H})$, str. $($ Aryl $)$ \\
\hline 2960 & v $(\mathrm{C}-\mathrm{H})$, str. $\left(-\mathrm{CH}_{3}\right)$ \\
\hline $1690(\mathrm{~s}), 1680(\mathrm{~s})$ & v $\mathrm{C}=\mathrm{O}$, str. (Five membered ring) \\
\hline $1635(\mathrm{~s}), 1470(\mathrm{~s})$ & v $\mathrm{C}=\mathrm{N}$, str. \\
\hline $1600(\mathrm{~s}), 1510(\mathrm{~s}), 1470(\mathrm{~s})$ & v $\mathrm{C}=\mathrm{C}$, str. (Benzene ring) \\
\hline $1340-1250(\mathrm{~s})$ & v C-N, str. (Aniline) \\
\hline $1030-960(\mathrm{~s})$ & v $\mathrm{C}-\mathrm{O}$, str. (five membered ring) \\
\hline $880(\mathrm{~s}), 760(\mathrm{~s}), 720(\mathrm{~s})$ & $v(\mathrm{C}-\mathrm{H})$, str. (Benzene ring) \\
\hline \multicolumn{2}{|l|}{ (B) PMR $\left(\mathrm{CDCl}_{3}\right) \delta$} \\
\hline $2.70(\mathrm{~s})$ & $3 \mathrm{H}$ \\
\hline $7.15-7.60(\mathrm{~m})$ & $5 \mathrm{H},\left(\right.$ Aniline ring, $\mathrm{C}_{2}-\mathrm{H}$ to $\left.\mathrm{C}_{6}-\mathrm{H}\right)$ \\
\hline $7.60-7.80(\mathrm{~m})$ & $4 \mathrm{H},\left(\right.$ Benzene ring, $\mathrm{C}_{4}-\mathrm{H}$ to $\left.\mathrm{C}_{7}-\mathrm{H}\right)$ \\
\hline $12.40(\mathrm{br})$ & $1 \mathrm{H}, \mathrm{C}_{3}-\mathrm{O} \underline{\mathrm{H}}$ (enolic) \\
\hline
\end{tabular}

IR spectrum of this anil displayed an intense absorption at $1690 \mathrm{~cm}^{-1}$ its functional group region. This could be assigned to $\alpha, \beta$-unsaturated carbonyl group $(>\mathrm{C}=\mathrm{O})$ in five - membered ring. The absorption band appeared at 1635 $\mathrm{cm}^{-1}$ may be attributed to $>\mathrm{C}=\mathrm{N}$ stretching mode of vibrations. IR - band at $3610 \mathrm{~cm}^{-1}$ was observed in IR spectrum of ligand. This is assigned to $v(\mathrm{O}-\mathrm{H})$ phenolic group.
Besides the presence of IR bands of principal functional groups The IR absorption bands were observed such as, band at $3060 \mathrm{~cm}^{-1}$ due to $v \mathrm{C}-\mathrm{H}$ (Aryl) at $2960 v \mathrm{C}-\mathrm{H}(-$ $\mathrm{CH}_{3}$ ), at $1600(\mathrm{~s}), 1500(\mathrm{~s}), 1470(\mathrm{~s})$ due to $v \mathrm{C}=\mathrm{C}$ stretch in benzene ring, at 1340-1250(s), vC-N stretch (Aniline) at 1030-960(s) region due to $v$ C-O stretch (five membered ring) and IR bands at $880(\mathrm{~s}), 760(\mathrm{~s})$ and $720(\mathrm{~s}) \mathrm{cm}^{-1}$ could be attributed to $v \mathrm{C}-\mathrm{H}$ stretch in benzene ring. 
$90 \mathrm{MHz}$ PMR spectrum of these anil showed the signals at the expected positions. In the aliphatic region of the spectrum at $\delta 2.70$, was observed a three - protons sharp singlet due to $-\mathrm{CH}_{3}-\mathrm{C}=\mathrm{N}-$. In the aromatic region of the spectrum all the nine protons appeared in a group of closely spaced clusters of resonance in the range $\delta 7.15-7.60(5 \mathrm{H}$, aniline) and $\delta 7.60-7.80(4 \mathrm{H}$, benzene) respectively. The $\mathrm{C}_{3}-\mathrm{OH}$ (phenolic) proton as usual showed a broad signal at $\delta 12.40$. This fact was supported by IR spectrum of the anil which was transparent in the region $3400-3200 \mathrm{~cm}^{-1}$. This suggests that the anil exists exclusively in the enol form.

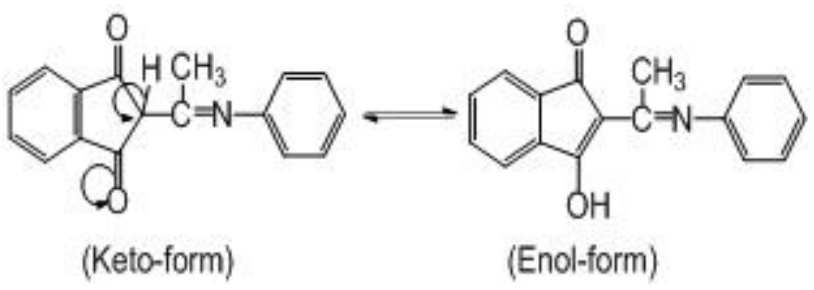

The anil gave a positive ferric chloride test.

A persual of the literature revealed that only a few sporadic reports $^{16,} 17$ have appeared on the mass spectral fragmentation of Schiff's bases. However, no study has ever been made to elucidate the mass spectral fragmentation of Schiff's bases derived from 2acetlylindan-1,3-dione. Therefore, mass spectral study these anils have been attempted. The mass spectra of the anils in the present investigation displayed command mode of fragmentation. The substituent present in the aromatic amine moiety of the anil affected the relative intensities of the ions having a similar origin. The mass spectrum of this anil showed the molecular ion appearing as the base peak at $\mathrm{m} / \mathrm{e} 263$.

Table - 2: The physical state, colour and magnetic moment data of the metal derivatives of the ligand, IEA

\begin{tabular}{|c|c|c|c|}
\hline $\begin{array}{l}\text { S. } \\
\text { No. }\end{array}$ & Complex & Colour and Physical state & $\begin{array}{l}\text { Magnetic moment } \mu \text { eff. } \\
\text { R.M. }\end{array}$ \\
\hline 1. & $\mathrm{Co} \mathrm{L}_{1} \mathrm{Cl} .3 \mathrm{CH}_{3} \mathrm{OH}$ & Dirty green, solid & 3.95 \\
\hline 2. & $\mathrm{Co}\left(\mathrm{L}_{1}\right)_{2} \cdot 2 \mathrm{CH}_{3} \mathrm{OH}$ & Light green, solid & $\ldots .$. \\
\hline 3. & $\mathrm{Ni} \mathrm{L}{ }_{1} \mathrm{Cl} .3 \mathrm{CH}_{3} \mathrm{OH}$ & Yellow brown, solid & 3.35 \\
\hline 4. & $\mathrm{Ni}\left(\mathrm{L}_{1}\right)_{2} .2 \mathrm{CH}_{3} \mathrm{OH}$ & Yellow brown, solid & $\ldots \ldots$ \\
\hline 5. & $\mathrm{Cu} \mathrm{L}_{1} \mathrm{Cl}$ & Green, solid & 1.74 \\
\hline 6. & $\mathrm{Cu}\left(\mathrm{L}_{1}\right)_{2}$ & Green, solid & $\ldots \ldots$ \\
\hline 7. & $\mathrm{Zn} \mathrm{L}{ }_{1} \mathrm{Cl}$ & Yellowish green, solid & 0.00 \\
\hline 8. & $\mathrm{Zn}\left(\mathrm{L}_{1}\right)_{2}$ & Yellowish green, solid & $\ldots \ldots$ \\
\hline 9. & $\mathrm{Cd} \mathrm{L}_{1} \mathrm{Cl}$ & Yellowish green & 0.00 \\
\hline 10. & $\mathrm{Cd}\left(\mathrm{L}_{1}\right)_{2}$ & Yellowish green & $\ldots \ldots$ \\
\hline 11. & $\mathrm{Fe} \mathrm{L}_{1} \mathrm{Cl}_{2} .2 \mathrm{CH}_{3} \mathrm{OH}$ & Yellowish green & 5.85 \\
\hline 12. & $\mathrm{Fe}\left(\mathrm{L}_{1}\right)_{2} \mathrm{Cl} . \mathrm{CH}_{3} \mathrm{OH}$ & Yellowish green & $\ldots \ldots$ \\
\hline 13. & $\mathrm{Fe}\left(\mathrm{L}_{1}\right)_{3}$ & Yellowish green & $\ldots \ldots$ \\
\hline 14. & $\mathrm{~V} \mathrm{~L}_{1} \mathrm{Cl}_{2} .2 \mathrm{CH}_{3} \mathrm{OH}$ & Yellow green, solid & 3.80 \\
\hline 15. & $\mathrm{~V}\left(\mathrm{~L}_{1}\right)_{2} \mathrm{Cl} . \mathrm{CH}_{3} \mathrm{OH}$ & Yellowish green, solid & $\ldots$ \\
\hline 16. & $\mathrm{~V}\left(\mathrm{~L}_{1}\right)_{3}$ & Yellowish green, solid & $\ldots \ldots$ \\
\hline 17. & $\mathrm{Cr} \mathrm{L}_{1} \mathrm{Cl}_{2} \cdot 2 \mathrm{CH}_{3} \mathrm{OH}$ & Redish brown, solid & 3.85 \\
\hline 18. & $\mathrm{Cr}\left(\mathrm{L}_{1}\right)_{2} \mathrm{Cl} . \mathrm{CH}_{3} \mathrm{OH}$ & Redish brown, solid & $\ldots \ldots$ \\
\hline 19. & $\mathrm{Cr}\left(\mathrm{L}_{1}\right)_{3}$ & Redish brown, solid & $\ldots \ldots$ \\
\hline
\end{tabular}

Where, $\mathrm{L}_{1}^{-}=$Ligand anion $\left(\mathrm{C}_{17} \mathrm{H}_{12} \mathrm{O}_{2} \mathrm{~N}\right)^{-}$

\section{Metal-derivatives}

The metal derivatives of the anil have been prepared in different molar ratios of the metal ion to ligand by refluxing the reaction mixture in methanol solvent on water bath for 1 - 3 hours. The coloured solid complexes were obtained. The solid products were found insoluble in water, alkalies and common organic solvents. The complexes are thermally stable and infusible at higher temperature $300^{\circ} \mathrm{C}$ ). These characteristics indicate the complexes to be polymeric in nature.

\section{Structure:}

The structure of the metal complexes has been established by spectral studies, magnetic moment values and molar conductivity measurements. The colour, physical state and magnetic moment values of the complexes have been given in table-2.

\section{IR and PMR Spectral Studies:}

The observed IR spectral data of the metal complexes have been placed in the table -3 . 
Table 3: The principal IR spectral data of the (1:1) metal derivatives of the ligand, Indeno - Ethylidine - aniline $\left(\mathrm{L}_{1} \underline{\mathrm{H}}\right)(\mathrm{IEA})$ and their assignments

\begin{tabular}{|c|c|c|c|c|c|c|c|c|c|}
\hline $\begin{array}{l}\text { S. } \\
\text { No. }\end{array}$ & $\begin{array}{l}\text { Co. } \mathrm{L}_{1} \mathrm{Cl} . \\
3 \mathrm{CH}_{3} \mathrm{OH} \\
\mathrm{cm}^{-1}\end{array}$ & $\begin{array}{l}\mathrm{NiL}_{1} \mathrm{Cl} . \\
3 \mathrm{CH}_{3} \mathrm{OH} \mathrm{cm} \mathrm{cm}^{-1}\end{array}$ & $\begin{array}{l}\mathrm{CuL}_{1} \mathrm{Cl} \\
\mathrm{cm}^{-1}\end{array}$ & $\begin{array}{l}\mathrm{ZnL}_{1} \mathrm{Cl} \\
\mathrm{cm}^{-1}\end{array}$ & $\begin{array}{l}\mathrm{CdL}_{1} \mathrm{Cl} \\
\mathrm{cm}^{-1}\end{array}$ & $\begin{array}{l}\mathrm{FeL}_{1} \mathrm{Cl}_{2} . \\
2 \mathrm{CH}_{3} \mathrm{OH} \mathrm{cm}{ }^{-1}\end{array}$ & $\begin{array}{l}\mathrm{VL}_{1} \mathrm{Cl}_{2} . \\
2 \mathrm{CH}_{3} \mathrm{OH} \mathrm{cm}- \\
1\end{array}$ & $\begin{array}{l}\mathrm{CrL}_{1} \mathrm{Cl}_{2} . \\
2 \mathrm{CH}_{3} \mathrm{OH} \mathrm{cm} \mathrm{cm}^{-1}\end{array}$ & Assignments \\
\hline 1. & $\begin{array}{ll}---- \\
\end{array}$ & $\begin{array}{ll}--- \\
\end{array}$ & ---- & $\begin{array}{ll}--- \\
\end{array}$ & $\begin{array}{ll}--- \\
\end{array}$ & $\begin{array}{ll}--- \\
\end{array}$ & ---- & --- & $v(\mathrm{O}-\mathrm{H})($ Phenolic) \\
\hline 2. & $3070(\mathrm{~s})$ & $3050(\mathrm{~s})$ & $3050(\mathrm{~s})$ & $3065(\mathrm{~s})$ & $3040(\mathrm{~s})$ & $3050(\mathrm{~m})$ & $3070(\mathrm{~s})$ & $3060(\mathrm{~s})$ & $v(\mathrm{C}-\mathrm{H})(\mathrm{Aryl})$ \\
\hline 3. & $2940(\mathrm{~m})$ & $2960(\mathrm{~s})$ & $2920(\mathrm{~s})$ & $2945(\mathrm{~s})$ & $2940(\mathrm{~m})$ & $2950(\mathrm{~m})$ & $2970(\mathrm{~s})$ & $2940(\mathrm{~s})$ & $\begin{array}{l}v(\mathrm{C}-\mathrm{H}) \\
\left(-\mathrm{CH}_{3}\right)\end{array}$ \\
\hline 4 & $1670(s)$ & $1665(\mathrm{~s})$ & $1680(\mathrm{~s})$ & $1670(\mathrm{~s})$ & $1660(\mathrm{~s})$ & $1670(\mathrm{~s})$ & $1675(\mathrm{~s})$ & $1650(\mathrm{~s})$ & $\begin{array}{l}v \quad(\mathrm{C}=\mathrm{O}) \quad(\text { five } \\
\text { membered ring) }\end{array}$ \\
\hline 5 & 1620,1450 & $1615,1440(\mathrm{~s})$ & $1630,1450(\mathrm{~s})$ & $1620,1440(\mathrm{~s})$ & $1625,1440(\mathrm{~s})$ & $\begin{array}{ll}\begin{array}{l}1620, \\
(s)\end{array} & 1430 \\
\end{array}$ & $\begin{array}{ll}1610, & 1440 \\
(s) & \end{array}$ & $1630,1450(\mathrm{~s})$ & $v(\mathrm{C}=\mathrm{N}), \mathrm{str}$ \\
\hline 6 & $\begin{array}{l}1600(\mathrm{~s}), 1500 \\
(\mathrm{~s}) 1470(\mathrm{~s})\end{array}$ & $\begin{array}{l}1610(\mathrm{~s}), 1520 \\
(\mathrm{~s}) 1460(\mathrm{~s})\end{array}$ & $\begin{array}{l}1610(\mathrm{~s}) 1490 \\
\text { (s) } 1450(\mathrm{~s})\end{array}$ & $1590(\mathrm{~s}) 1460(\mathrm{~s})$ & $1610(\mathrm{~s}) 1510(\mathrm{~s})$ & $\begin{array}{l}1600(\mathrm{~s}) 1500 \\
(\mathrm{~s})\end{array}$ & $\begin{array}{ll}1605 & (\mathrm{~s}) \\
1515(\mathrm{~s}) & \end{array}$ & $\begin{array}{lll}1600 & (\mathrm{~s}) & 1590 \\
(\mathrm{~s}) & & \end{array}$ & $\begin{array}{l}v(\mathrm{C}=\mathrm{C}) \text { (benzene } \\
\text { ring) }\end{array}$ \\
\hline 7 & $1340-1240(\mathrm{~s})$ & $1340-1240(\mathrm{~s})$ & $1350-1240(\mathrm{~s})$ & $1340-1250(\mathrm{~s})$ & $1345-1245(\mathrm{~s})$ & $1340-1250(\mathrm{~s})$ & $1330-1240(\mathrm{~s})$ & $1340-1250(\mathrm{~s})$ & $v(\mathrm{C}-\mathrm{N})($ aniline $)$ \\
\hline 8 & $1040-960(\mathrm{~s})$ & $1050-950(\mathrm{~s})$ & $1030-960(\mathrm{~s})$ & $1035-450(\mathrm{~s})$ & $1050-950(\mathrm{~s})$ & $1030-950(\mathrm{~s})$ & $1040-940(\mathrm{~s})$ & $1020-940(\mathrm{~s})$ & $\begin{array}{l}v(\mathrm{C}-\mathrm{O}) \quad \text { five } \\
\text { membered ring }\end{array}$ \\
\hline 9 & $\begin{array}{l}870 \quad(\mathrm{~s}), 750 \\
(\mathrm{~s}), 720(\mathrm{~s})\end{array}$ & $\begin{array}{l}880(\mathrm{~s}), 750(\mathrm{~s}), \\
730(\mathrm{~s})\end{array}$ & $\begin{array}{l}850(\mathrm{~s}), 740(\mathrm{~s}) \\
730(\mathrm{~s})\end{array}$ & $\begin{array}{l}870(\mathrm{~s}), 760 \quad(\mathrm{~s}) \\
730(\mathrm{~s})\end{array}$ & $\begin{array}{l}880(\mathrm{~s}), 750(\mathrm{~s}) 720 \\
(\mathrm{~s})\end{array}$ & $\begin{array}{l}860(s), 740 \\
(s) 730(s)\end{array}$ & $\begin{array}{ll}860 & (s) \\
750(s) & 720(s)\end{array}$ & $\begin{array}{l}850(\mathrm{~s}) 770 \quad(\mathrm{~s}) \\
720(\mathrm{~s})\end{array}$ & $\begin{array}{l}v \quad(\mathrm{C}-\mathrm{H}) \\
\text { (benzene ring) }\end{array}$ \\
\hline 10 & $\begin{array}{l}350(\mathrm{~s}), 810- \\
800(\mathrm{~m})\end{array}$ & $\begin{array}{l}360 \quad(\mathrm{~s}) \quad 810- \\
800(\mathrm{~m})\end{array}$ & $\begin{array}{l}325(\mathrm{~s}) \\
810(\mathrm{~m})\end{array}$ & $\begin{array}{lll}\begin{array}{l}350 \\
(\mathrm{~s})\end{array} & (\mathrm{s}) & 810-800 \\
\end{array}$ & $370(\mathrm{~s}) 800-790(\mathrm{~s})$ & $\begin{array}{lll}380 & (\mathrm{~s}) & 810- \\
800 & & \\
\end{array}$ & $\begin{array}{ll}330 & (\mathrm{~s}) 820- \\
810 & \\
\end{array}$ & 320 (s) $810-800$ & $v(\mathrm{M}-\mathrm{O})$ stretch \\
\hline 11 & $250(\mathrm{~s})$ & $240(\mathrm{~m})$ & $260(\mathrm{~s})$ & $228(\mathrm{~s})$ & $260(\mathrm{~m})$ & $276(\mathrm{~s})$ & $250(\mathrm{~s})$ & $240(\mathrm{~s})$ & $v(\mathrm{M}-\mathrm{Cl})$ stretch \\
\hline 12 & $420(\mathrm{~s})$ & $430(\mathrm{~s})$ & $430(\mathrm{~s})$ & $435(\mathrm{~s})$ & $430(\mathrm{~s})$ & $420(\mathrm{~s})$ & $430(\mathrm{~s})$ & $435(d)$ & $v(\mathrm{M}-\mathrm{N})$, stretch \\
\hline
\end{tabular}


90MHz PMR spectrum of the metal derivatives of anil supported the formation of the metal complexes. Most of the PMR signal observed in the PMR spectrum of the aniL (Indeno-Ethyledene-aniline) were present at the expected positions and spectral regions but a broad PMR signal at $\delta 12.40$ due to $\mathrm{C}_{3}-\mathrm{OH}$ (enolic) proton did not appear due to metal-ligand bonding at this centre. Disappearance of $\mathrm{C}_{3}-\mathrm{OH}$ proton signal confirm the formation of metal. Complexes of this Schiff's base (IEA).

\section{The magnetic moment measurement:}

The magnetic moments of metal derivatives were measured at room temperature, $25^{\circ} \mathrm{C}$. The observed magnetic moment data are presented in table -2 .

The cobalt (II) complexes with indeno-ethylidene-aniline show their magnetic moment in 3.90-3.95 BM range. The magnetic moment values normally observed for $\mathrm{d}^{7}$ spin free complexes lie in the range 4.30-5.20BM. The observed magnetic moment of Co (II) complexes with this anil imply that the system is magnetically concentrated.

Like other complexes Ni (II) derivatives of IEA ligand also exhibit antiferromagnetism at room temperature and their magnetic moment. Values are found to be $2.95 \mathrm{BM}$ the expected magnetic moment values of $\mathrm{d}^{8}$ spin free complexes lie in the range 2.90 to $3.40 \mathrm{BM}$, the observed magnetic moment of $\mathrm{Cu}$ (II) $\left(\mathrm{d}^{9}\right)$ complexes in $1.74 \mathrm{BM}$. The expected magnetic moment values for spin free $\mathrm{d}^{9}$ system lie in the range 1.75-1.80 BM. Zn (II), Cd (II) complexes show zero value of magnetic moment. Thus they are diamagnetic as expected. The observed magnetic moment values in Fe (III), V (III) and $\mathrm{Cr}$ (III) complexes are 5.85 BM. 3.80 BM. and 3.85 BM. showing them paramagnetic and ferromagnetic in behavior.

\section{Molar conductance Measurements:}

The molar conductance of the metal derivatives (1:1 molar complexes) was measured in the anhydrous solvent, dimethyl sulphoxide (DMSO) at room temperature, $25^{\circ} \mathrm{C}$. The measured molar conductance values are presented in table -4 . The observed molar conductance values of the metal derivatives (1:1 complexes) with the ligand indeno-ethylidene-aniline were found in the range 160 to 220 mhos. $\mathrm{cm}^{2}$ g.mole ${ }^{-1}$ shows that the complexes are partially ionic in nature. Though they are insoluble common organic solvents. Thus, they are polymeric covalent compounds. But the possibility of their partial ionic nature cannot be ruled out with these molar conductance values. The metal derivatives are solids bearing high M.P.'s (above $200^{\circ} \mathrm{C}$ ).

\section{Mass - Spectral Studies:}

The mass spectral studies of the indeno-ethylideneaniline (ligand) and few of its metal derivatives have been carried out the mass spectra of these compounds displayed the molecular ion peaks at the expected place and also showed an interesting fragmentation pattern.

The mass spectra of the present Schiff's base (IEA) and its metal derivatives showed intense molecular ion peaks which also constituted the base peak of each spectrum. All these spectra also showed $\mathrm{M}^{+}-1$ ion peaks of variable intensity. In the mass spectra of indeno-ethylideneaniline anil $\mathrm{M}^{+}$ion peak was observed at $\mathrm{m} / \mathrm{z} 263$ (100) and $\mathrm{M}^{+}-1$ ion peak was observed at $\mathrm{m} / \mathrm{z} 262(60)$ intensity. The most probable structure for the $\mathrm{M}^{+}-1$ ion peak.

Table 4: Molar conductivity data of 1:1 metal complexes measured at room temperature, $25^{0} \mathrm{C}$.

\begin{tabular}{|c|c|c|c|c|c|c|}
\hline $\begin{array}{l}\text { S. } \\
\text { No. }\end{array}$ & Complex with IEA $\left(\mathrm{L}_{1}\right)$ & $\begin{array}{l}\text { Conc. } \\
\text { solution }\end{array}$ & $\begin{array}{l}\text { Observed } \\
\text { conductance } \\
\text { micro mhos }\end{array}$ & $\begin{array}{l}\text { Cell } \\
\text { constant }\end{array}$ & $\begin{array}{l}\text { Specific } \\
\text { conductance } \\
\text { micromho/ } \\
\mathrm{cm}\end{array}$ & $\begin{array}{l}\text { Molar } \\
\text { conductance } \\
\text { mho.cm } / \mathrm{g} . \\
\text { mol }\end{array}$ \\
\hline 1. & $\mathrm{CoL}_{1} \mathrm{Cl} .3 \mathrm{CH}_{3} \mathrm{OH}$ & $1 \times 10^{-3} \mathrm{M}$ & 1600 & 0.1 & 160.0 & 160.0 \\
\hline 2. & $\mathrm{NiL}_{1} \mathrm{Cl} .3 \mathrm{CH}_{3} \mathrm{OH}$ & $1 \times 10^{-3} \mathrm{M}$ & 1665 & 0.1 & 166.5 & 166.5 \\
\hline 3. & $\mathrm{Cu} \mathrm{L}{ }_{1} \mathrm{Cl}$ & $1 \times 10^{-3} \mathrm{M}$ & 1750 & 0.1 & 175.0 & 175.0 \\
\hline 4. & $\mathrm{Zn} \mathrm{L}{ }_{1} \mathrm{Cl}$ & $1 \times 10^{-3} \mathrm{M}$ & 1740 & 0.1 & 174.0 & 174.0 \\
\hline 5. & $\mathrm{Cd} \mathrm{L}_{1} \mathrm{Cl}$ & $1 \times 10^{-3} \mathrm{M}$ & 1700 & 0.1 & 170.0 & 170.0 \\
\hline 6. & $\mathrm{FeL}_{1} \mathrm{Cl}_{2} \cdot 2 \mathrm{CH}_{3} \mathrm{OH}$ & $1 \times 10^{-3} \mathrm{M}$ & 2150 & 0.1 & 215.0 & 215.0 \\
\hline 7. & $\mathrm{VL}_{1} \mathrm{Cl}_{2} \cdot 2 \mathrm{CH}_{3} \mathrm{OH}$ & $1 \times 10^{-3} \mathrm{M}$ & 2200 & 0.1 & 220.0 & 220.0 \\
\hline 8. & $\mathrm{CrL}_{1} \mathrm{Cl}_{2} \cdot 2 \mathrm{CH}_{3} \mathrm{OH}$ & $1 \times 10^{-3} \mathrm{M}$ & 2180 & 0.1 & 218.0 & 218.0 \\
\hline
\end{tabular}

Seems to be one derived through the loss of the most acidic hydrogen located at $\mathrm{C}_{2}$ of the indan-dione moiety in the case of this ligand (IEA), the fragmentation process commences with the elision of a $\mathrm{CH}_{3}$ radical from the molecular ion $\left(\mathrm{M}^{+}, \mathrm{m} / \mathrm{z} 263\right)$. The resultant $\left(\mathrm{M}^{+}-\mathrm{CH}_{3}\right)$ ions subsequently loss a $\mathrm{CN}(\mathrm{m} / \mathrm{z} 26)$ radical to afford the ions, $\mathrm{m} / \mathrm{z} 222$ (II) and , m/z 248 (24). These ions could also arise partially through the direct loss of methyl cyanide from the molecular ion. As shown below:

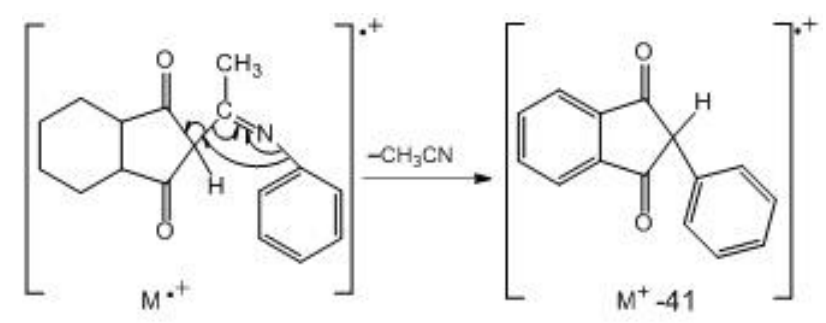


The loss of methyl cyanide subsequent to $\alpha$-cleavage in the alkyl side chain during electron impact-induced fragmentation of Schiff's base derived from pyridine-2carboxylaldehyde and isopropyl amine has been reported $^{19}$. This supports elison of methyl group and methyl cyanide through $\alpha$-cleavage from the molecular ion. This anil (IEA) exhibited prominent peaks corresponding to the loss of $\mathrm{M}^{+}-77$ (Phenyl) at $\mathrm{m} / \mathrm{z} 262$ and an ion at $\mathrm{m} / \mathrm{z}(222)$ and $\mathrm{m} / \mathrm{z} 236(37 \%)$.

The cobalt (II), Nickel (II) and Copper (II) derivatives of this anil (IEA) displayed mass spectra and fragmentation pattern similar to mass spectra of the anil (ligand) molecular ion peak $\mathrm{M}^{+}$and $\mathrm{M}^{+}-1$ base peaks were observed at expected positions with variable intensities. The molecular ion peaks at $\mathrm{m} / \mathrm{z} 453$ (100), $\mathrm{m} / \mathrm{z} 452$ (100) and $\mathrm{m} / \mathrm{z} 361$ (100) were observed in mass spectra of $1: 1$ ratio complexes of $\mathrm{Co}$ (II), $\mathrm{Ni}$ (II) and $\mathrm{Cu}$ (II) respectively. In spectra of these complexes molecular base ion peaks were observed at $\mathrm{m} / \mathrm{z} 452, \mathrm{~m} / \mathrm{z} 451$ and $\mathrm{m} / \mathrm{z} 360$ respectively. The loss of methyl radical $\left(. \mathrm{CH}_{3}\right)$ $\mathrm{m} / \mathrm{z} 15$ and methyl cyanide $\mathrm{m} / \mathrm{z} 41$ were observed in mass spectra of the complexes similar to these fragmentation in mass spectra of the ligand (IEA).

\section{Electronic spectral studies}

The electronic spectra of 1:1 molar ratio complexes of cobalt (II), Nickel (II) and Copper (II) with the ligand indeno-ethylidene-aniline (IEA) have been studied.

The diffused transmittance electronic spectra of dirty green Cobalt (II) complex, $\mathrm{Co}\left[\mathrm{C}_{17} \mathrm{H}_{12} \mathrm{O}_{2} \mathrm{~N}\right] \mathrm{Cl} .3 \mathrm{CH}_{3} \mathrm{OH}$ displays and absorption band at $17400 \mathrm{~cm}^{-1}$. This could be assigned to $4 \mathrm{~T}_{1 \mathrm{~g}}(\mathrm{~F}) \quad 4 \mathrm{~T}_{2 \mathrm{~g}}(\mathrm{~F})\left(\mathrm{v}_{1}\right)$ transition. Three bands were observed at 16360, 17400, $19840 \mathrm{~cm}^{-1}$ in the range $1600-2200 \mathrm{~cm}^{-1}$ where most of the Cobalt (II) complexes have been observed. The observed band at $19840^{\mathrm{cm}-1}$ may be due to $4 \mathrm{~T}_{1 \mathrm{~g}}(\mathrm{~F}) \quad 4 \mathrm{~T}_{1 \mathrm{~g}}(\mathrm{p})\left(\mathrm{v}_{3}\right)$ transitions. This assignment shows a good agreement between proposed and experimental values $4 \mathrm{~T}_{1 \mathrm{~g}}(\mathrm{~F})$---> $4 \mathrm{~A}_{2 \mathrm{~g}}(\mathrm{~F})\left(\mathrm{v}_{2}\right)$ transitions, observed at $16360^{\mathrm{cm}-1}$. The presence of $\alpha$ bond at $19840^{\mathrm{cm}-1}$ may be due to a spin forbidden transition or due to the low symmetry effect of the ligand field. The $d-d$ transitions may be representated as :

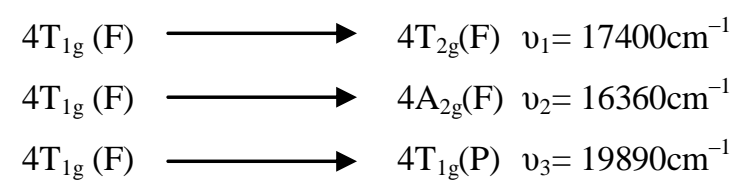

The electronic spectra of yellow brown nickel (II) complex $\mathrm{Ni}\left[\mathrm{C}_{17} \mathrm{H}_{12} \mathrm{O}_{2} \mathrm{~N}\right] \mathrm{Cl} .3 \mathrm{CH}_{3} \mathrm{OH}$ has been characterized as six coordinated $\mathrm{Ni}$ (II) complex. The electronic spectra showed three absorption bands, assigned to the frequencies as below:

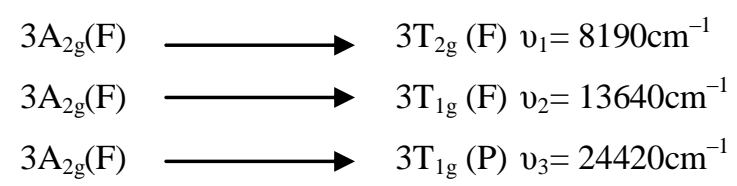

The $v_{1}$ band splits into two components with maxima at $7050^{\mathrm{cm}-1}$ and $8250^{\mathrm{cm}-1}$. This split may be due to lowing in symmetry of the complex from regular octahedral geometry which is expected in different coordinating species.

The electronic spectra of green Copper (II) complex, $\mathrm{Cu}\left[\mathrm{C}_{17} \mathrm{H}_{12} \mathrm{O}_{2} \mathrm{~N}\right] \mathrm{Cl}$ shows absorption and at $14290^{\mathrm{cm}-\mathrm{I}}$ and two shoulders at $16650^{\mathrm{cm}-1}$ and $10950^{\mathrm{cm}-1}$. These absorptions have been assigned earlier to distorted octahedral structure of Copper (II) complexes ${ }^{33-35}$. An additional band was observed at $23560^{\mathrm{cm}-1}$. This has been assigned to metal-metal interactions by some investigators. $^{33-35}$

The insolubility of the synthesized metal complex in water and common organic solvents and their infusibility at higher temperature $\left(300^{\circ}\right)$ suggest that the metal complexes of the ligand indeno-ethylidene aniline (IEA) are polymeric in nature. On the basis of elemental analysis, spectral studies, magnetic moment and molar conductivity measurements the structures of the bivalent and trivalent metal complexes have been suggested in which metal ions show tetra and hexa coordination geometry depending upon the nature of metal ions. The general structures of the metal complexes may be represented as below:

\section{1: General structures of bivalent metal-complexes.}

(a) 1:1-molar ratio complexes:-

(a)<smiles></smiles>

(b)

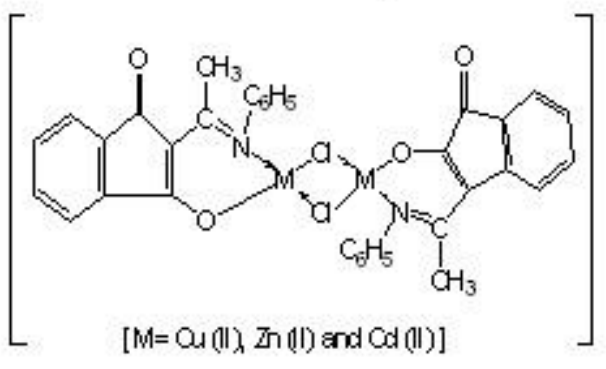

(b) 1:2-molar ratio complexes:-

(a)

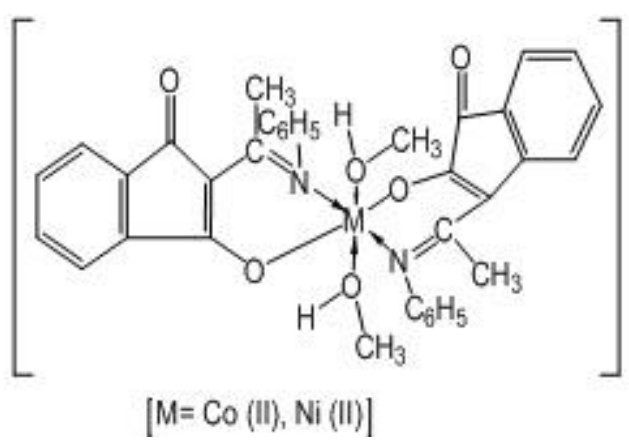


(b)

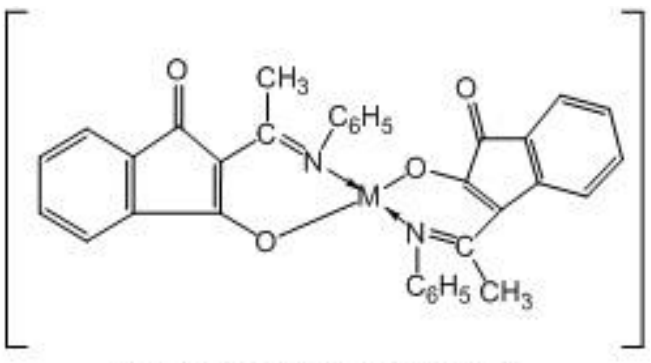

[ $\mathrm{M}=\mathrm{Cu}(\mathrm{II}), \mathrm{Zn}$ (II) and $\mathrm{Cd}$ (II) ] (ii) 1:2 molar complexes:

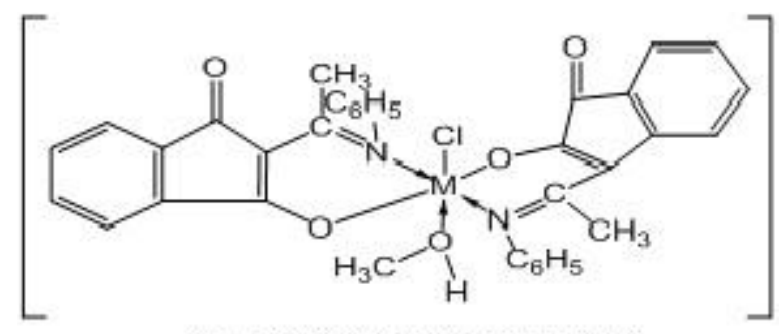

$[\mathrm{M}=\mathrm{Fe}(\mathrm{III}), \mathrm{V}$ (III)] and $\mathrm{Cr}$ (III)

(iii) 1:3 molar complexes:

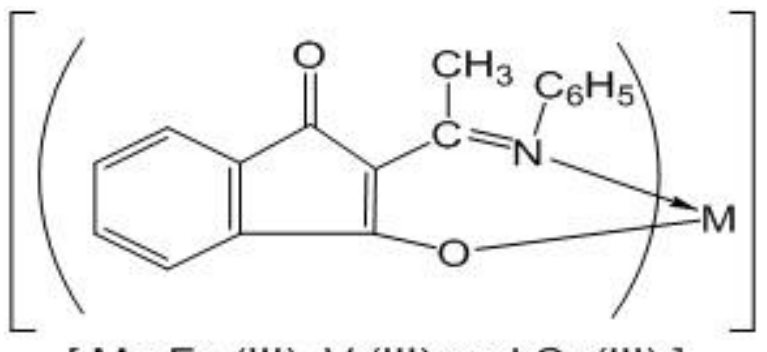

The Plausible mechanism of the reactions:

The plausible reaction mechanism of the formation of the ligands (anils) may be discussed as follows.

1. Mechanism of reactions of synthesis of Schiff's base step-I The starting material 2-substituted acetyl, 1, 3-dione formation:

(b)
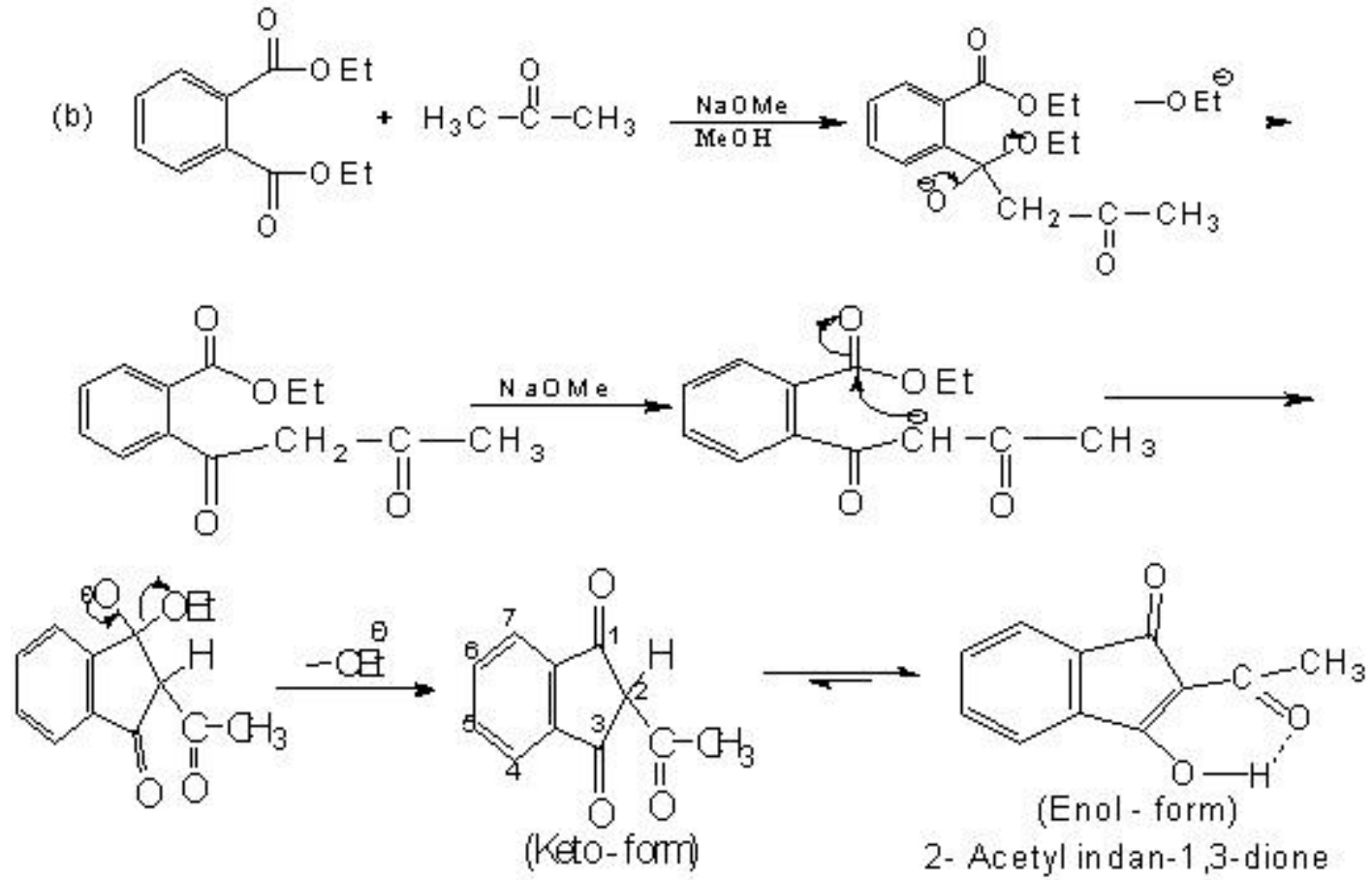
2. Mechanism of synthesis of sciff's bases (Anil):<smiles></smiles><smiles>[GeH2]</smiles><smiles>[R1]c1ccc(NC([R])(O)C2C(=O)c3ccccc3C2=O)cc1</smiles>

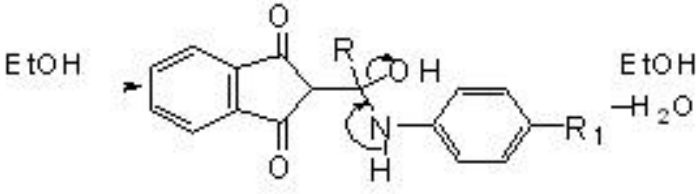<smiles>[R]C(=NC1CCC([R])CC1)C1C(=O)c2ccccc2C1=O</smiles>

Schiff's base

$\mathrm{R}=\mathrm{CH}_{3}, \mathrm{R}_{1}=\mathrm{H}$ Schiff base is IEA, Indeno-Ethylidene-aniline.

The $-\mathrm{O}-\mathrm{H}$ (Phenolic) group in five measured ring exists in hydrogen bonding with carboxyl group $(>\mathrm{C}=\mathrm{O})$ of the Ketones. The intra-hydrogen bonding in anils also stabilize the enolic form of the anils as shown below:<smiles>[R]C([Y])=Nc1ccc([R])cc1</smiles>

The structure of the anils has been characterized by their IR spectra which showed strong absorption at 1705,1650 and $1570 \mathrm{~cm}^{-1}$ along with other bands. These absorption may be assigned to non-bonded $\alpha, \beta$-unsaturated $>\mathrm{C}=\mathrm{O}$ group in a five membered ring Ketone, to chelated carbonyl, $>\mathrm{C}=\mathrm{O} \ldots . . \mathrm{H}-\mathrm{O}-$ and to enolic double bond respectively. The absence of any absorption in the region $3500-3100 \mathrm{~cm}^{-1}$ was in line with this assignments the enolic formulation for the anil gel and additional support by a positive ferric chloride test.

\section{Mechnism of complex formation reactions of the anils:}

The metal derivatives of the anils have been prepared in the reactions of metal salt and anils in the refluxing methanol. The reaction mechanism may be discussed as follows.<smiles>[X][X]C([X])([R])O[Na]</smiles><smiles>[X][M]OC1=C(C([R])=Nc2ccc([R7])cc2)C(=O)c2ccccc21</smiles>
(1:1 - Complex)

Similarly 1:1 and 1:2 - metal complexes may be formed. 
The spectral study of the ligands and metal complexes agreed with the formulation of ligands and their complexes in this mechanism due to presence of Ketonol isomerism existing in the ligand molecules. The IRspectra of the ligands displays strong absorptions at 1705,1650 and $1570 \mathrm{~cm}^{-1}$ along with other bands which may be assigned to non-bonded $\alpha, \beta$-unsaturated carbonyl group ( $>\mathrm{C}=\mathrm{O}$ ) (in five membered ring ), to chelated carbonyl $>\mathrm{C}=\mathrm{O}$----H-O- and to enolic double bond respectively. The absence of any absorption in the region 3500-3100 favours this assignments. The enolic formulation for the anils is supported by positive ferric chloride test. The presence of vM-O-c bands in the region $850-800 \mathrm{~cm}-1$ and $v \mathrm{M}-\mathrm{Cl}$ absopriton bands in the range $275-250 \mathrm{~cm}-1$ in the IR spectra of complexes support this mechanism.

\section{SUMMARY}

The coordination chemistry has been recognized as an unique branch of chemistry. Transition metal ions have unique capacity of complex formation with variety of ligands. This study has originated wide applications in different branches of Science and Engineering. A large number of coordination compounds are of biological importance.

The majority of the ligands are organic complexing agents. It has been found that the ligands containing nitrogen and phosphorus donor atoms are better complexing agents.

A large number of chemists throughout the world are currently engaged in the synthesis heterocyclic compounds with a view to evaluating their various biological properties. The present investigation aims at supplementing these efforts in the broad area of the synthesis of Schiff's bases (anils) such as $\alpha-(1,3-$ dioxoindan-2-yl)-elhylidene aniline (IEA), $\alpha-(1,3-$ dioxo-indan-2yl)-ethylidene -thiosemicarbazone (IETS), $\quad \alpha-1, \quad 3$-dioxoindan-2yl-benzylidene-aniline (IBT) and $\alpha-(1,3-$ dioxo-indan-2-yl)-benzylidene-ptoluidine (IBT) and their metal derivatives. The opportunity has also been taken to examine spectral properties of these compounds. The results of the present investigation have been described dealing with the synthesis and spectral studies of heterocyclic ligands with indan-1,3-dione moiety and their metal derivatives.

Indeno-ethylidene aniline $\left(\mathrm{C}_{17} \mathrm{H}_{13} \mathrm{O}_{2} \mathrm{~N}\right),\left(\right.$ IEA), $\left(\mathrm{L}_{1} \mathrm{H}\right)$ has been synthesized, characterized and used in preparation of their metal derivatives.

The general approach towards the synthesis of these Schiff's bases (ligands) consists two step synthesis. In the first step of synthesis the starting materials 2substituted, Acetyl-indane-1, 3-dione has been synthesized by claisen-condensation of diethylphathalate with acetone and accetophenone respectively in presence of sodium methoxide in methanol.

The second step involves the condensation 2-substituted indan-1, 3-dione ketones with aromatic primary amines and its appropriately substituted aromatic primary amines such as aniline.
The formulation and structure of the ligands have been screened by their chemical analysis, IR, PMR and massspectral studies.

The IR-spectrum of the anils displayed intense absorption in functional group region $1710-1620 \mathrm{~cm}^{-1}$ at $1690 \mathrm{~cm}^{-1}$ due to $\alpha, \beta$-unsaturated carbonyl group stretching frequency in five membered ring. The intense absorption at $1635-1630 \mathrm{~cm}^{-1}$ has been assigned to $\mathrm{vc}=$ $\mathrm{N}$ stretching vibration.

The metal derivatives of the synthesized Schiff's bases (anils) have been prepared by using a hydrous metal chlorides of the following metal ions: $\mathrm{Co}(\mathrm{II}), \mathrm{Ni}(\mathrm{II})$, $\mathrm{Cu}(\mathrm{II}), \mathrm{Zn}(\mathrm{II}), \mathrm{Cd}(\mathrm{II}), \mathrm{Fe}(\mathrm{III}), \mathrm{V}(\mathrm{III})$ and $\mathrm{Cr}(\mathrm{III})$.

The metal complexes of the anils have been prepared by refluxing metal salt and ligands solution in methanol solvent in different molar ratios of metal to ligand on water bath for 1-3 hours. The complexes obtained are colored solid products. The solid coloured complexes have been found insoluble in water, alkalies and common organic solvents. The complexes are thermally stable and infusible at higher temperatures $\quad\left(\sim 300^{\circ} \mathrm{c}\right)$. These characteristics observed in the metal complexes indicate the complexes to be polymeric in nature.

The structure of Indeno-ethylidene aniline has been confirmed by their mass-spectral studies. The massspectrum of the anils showed intense molecular ion peaks which constituted the base peak of each spectrum. These spectra also showed $\mathrm{M}^{+}+1$ and $\mathrm{M}^{+}-1$ ion peaks. The $\mathrm{M}^{+}-1$ ion peaks were of variable intensity. In the mass spectrum of IEA anil molecular ion peak $\left(\mathrm{M}^{+}\right)$ appeared at $\mathrm{m} / \mathrm{z}, 263(100)$ and $\mathrm{M}^{+}-1$ ion peak appeared at $\mathrm{m} / \mathrm{z}, 262(60)$.

In case of IEA anil the fragmentation process begins with the elision of a $\mathrm{CH}_{3}$ radical from the molecular ion. The resultant $\left(\mathrm{M}^{+}-\mathrm{CH}_{3}\right)$ ions subsequently lose a ${ }^{\circ} \mathrm{CN}(\mathrm{m} / \mathrm{z}$ 26) radical of afford ions corresponding to $\mathrm{M}^{+}-41$. Such loss of methyl cyanide from Schiff's base has been reported. Analogous to the loss of methyl cyanide from the anil IEA.

In addition to $\mathrm{M}^{+}-103$ ion at 222 . Theoretically, the $\mathrm{M}^{+}-$ $15\left(-\mathrm{CH}_{3}\right)$ ions could also loss a molecule of $\mathrm{CO}$ to afford ions at $\mathrm{M}^{+}-43$ or $\mathrm{M}^{+}-105$ in mass-spectrum of IEA.

The structure of the metal complexes of the ligands have been determined by IR, PMR, Mass specral studies, magnetic moments determinations and molar conductivity measurements.

It is evident that indenoquinolines and indenopyrazoles show various physiological properties such as potent analgesics, antipyretics, anti-inflammatory agents etc. Indenoquinolines and indenopyrazoles consist indan-1, 3-dione moiety which may be responsible for their biological activity. This suggests that indan-1, 3-dione derivatives may possible exhibit this property also with this fact is thoughts the present investigation has been carried out which includes synthesis of 2-substituted indan dione ketone and their schiff's bases (anils) by condensation of indan-1, 3-dione ketones with aniline. 


\section{REFERENCES}

1. Singh, V. K. Ph. D. Thesis, K.U. Kurukshetra (Harayana) Dec. 1993

2. Fox, H. H., J. Org. Chem. 1952, 17, 555.

3. Dhumwad SD, Gudasi K.B, Gudar TR., Ind. J. Chem., 1994, 33A, 320.

4. French, F.A. and Banz, E.J., J. Cancer Res. 1966, 36, 1638.

5. Mishra, V. S., Verma, R. S. and Agarwal, S., J. Ind. Chem. Soc. 1975, 52, 981.

6. Rai BK. Ind. Council of Chem. 2005, 22(2), 5.

7. Rai BK. and Baluni, A. Asian J. Chem. 2001, 13, 1589-1595

8. Rai BK. and Kumar, M., J. Ind. Council Chem. 2003, 20, 22.

9. Klayman, D. L. Scovill, J.P., Bartosevich, J. F., Bruch J. J. Med. Chem. 1983, 26, 35.

10. Philip, V. Suni, V. Kurup, M.R.P Netaji, M. Polyhedron, 2006, 25, 1931.

11. French, F. A. Blanz jr. E. J. J. Med. Chem. 1996, 9, 585.

12. Das, M., Living stone, S. E., Br. J. Cancer, 1978, 37, 466.

13. Dobak. A. S., Clayman, D.L., Dickson, L.T. Scovill, J.P. Tramont, E. C. Antimicrob, Agents Chemother, 1980, 1827.

14. Usman, A. Razak, I. A., Chantrapromma, S., Fun. A. H. K., Acta cryst, $\underline{\text { C }, ~ 2002, ~} 461$.

15. Clayman, D. L. Lin, A. J., Mc Call, J. W., J. Med. Chem. 1994, 34, 1422.

16. Shipman, G., C. Smith, H., Drach, J. C., Clayman, D. L., Antiviral Res. 1996, 6, 197.

17. El. Sawaf, A.K., West, D. X., El. Bahnasway, R. H. El. Said, F.A. Transition. Med. Chem. 1998, 23, 227.

18. Atonini, I., Claudi, P., Franchetti, M., Grifantini, S., Moore, A.E., j. Med. Chem. 1977, 20, 447.

19. Sonawane, P., Kumbhar, A., Padhye, S.B., Butcher, R.J., Transition Met. Chem. 1994,19, 277.

20. Thomas, J., Parmeswaran, G., Asian, J. Chem. 2002, 14 , 1354.

21. Petrow, V. and Kahan, H.J., J. Chem. Soc. 1949, 2128.
22. Norman, H. and Cromwell, A., J. Org. Chem. 1961, 26, 3812-17.

23. Coombes, R. V. and Haulihan, W. J. J. Heterocyclic. Chem. $1971, \underline{8}, 855$.

24. Palta, N., Rao, B.V. Dubey, S. N. and Puri, D. M., Polyhedron, 1984, 3, 527.

25. Mehrotra, R. C. and Puri, D. M., J. Less. Common metals 1961, 3, 253.

26. Mehrotra, R. C. and Puri, D. M., J. Ind. Chem. Soc. 39 (1962) 447, 499.

27. Puri, D.M. Ph.D. thesis, university of Gorakhpur (1962).

28. Vogel,A.I. "Quantitative Inorganic analysis" Longman's Green \& Co. Ltd. $5^{\text {th }}$ Ed., John Wiley \& Sons Inc. New York (1989) P. 480.

29. Vogel, A. I., Jeffery,G.H., Bassett, J., Mendhoz, J. and Denny, R.c., "Quantitative Chemicsl Analysis Co. Ltd." $5^{\text {th }}$ Edn. John Wiley \& sons, Inc. New York, (1989) P. 457.

30. Vogel, A. I., Jeffery,G.H., Bassett, J., Mendhoz, J. and Denny, R.c., "Quantitative Chemicsl Analysis Co. Ltd." $5^{\text {th }}$ Edn. John Wiley \& sons, Inc. New York, (1989) P. 454.

31. Vogel, A. I., Jeffery,G.H., Bassett, J., Mendhoz, J. and Denny, R.c., "Quantitative Chemicsl Analysis Co. Ltd." $5^{\text {th }}$ Edn. John Wiley \& sons, Inc. New York, (1989) P. 462.

32. Vogel, A. I., Jeffery,G.H., Bassett, J., Mendhoz, J. and Denny, R.c., "Quantitative Chemicsl Analysis Co. Ltd." $5^{\text {th }}$ Edn. John Wiley \& sons, Inc. New York, (1989) P. 455.

33. Figgis, B. N. "Introduction to ligand field" wiley interscience, New York, 1976.

34. G. S. Sanyal, A. B. Modak, K. and Mubi, A. K., Ind. J. chem. 21A (1982) 1044.

35. Mc. Farlane, W and whrte, RFM, "Techniques of high Resolution Nuclear Magnetic Resonance spectroscopy" (Butterworths, London) 1972, 125. 